\title{
Factors Influencing Personal Finance Management Among the Students of University College of Technology Sarawak (UCTS)
}

\author{
Utin Roziana Binti Gusti Asmadi, \\ School of Foundation Studies, \\ University College Technology Sarawak, \\ Sibu, Sarawak, Malaysia. \\ utinroziana@gmail.com
}

\begin{abstract}
Young adults generally learn their skills from parents and teachers as children. However, parents often overlook teaching financial skills, such as budgeting and investing, while their children are still living at home. Consequently, children are forced to learn how to handle their finances after leaving home, entering colleges or universities. Sometimes they may make mistakes that would cost them several years of repayment of loans. This research therefore examined the prime factors of University College of Technology Sarawak (UCTS) students on managing their personal finance, and the relations between each influencing factor with the youth financial knowledge at UCTS by the using Theory of Planned Behaviour (TBP). The resulting analysis and interpretation provided a description of the influence of cash management and credit management behaviour related to students' financial knowledge. The qualitative method in this study derived from a constructive perspective. The outcome of this study is that the influence of family members is important yet complicated for personal financial management behaviour. Based on the findings, three primary categories with supporting factors emerged as the critical components of each category. These three primary categories represent a conceptual framework for the students' personal financial management.
\end{abstract}

Keywords: personal finance, students, University College of Technology Sarawak (UCTS), Theory Planned Behaviour (TPB), cash management, credit management, youth financial knowledge

\section{Introduction}

A majority of students rely on study loans to get them through colleges or universities. Furthermore, some students borrow too much money while they are in school to fulfil not only their education needs but also for their personal needs. Therefore, this study specifically focused on the factors that influence personal finance management among students at University College of Technology Sarawak (UCTS).

Although some of the financial knowledge patterns in western countries show the measurement of financial literacy over three different investments and saving concepts, there are other factors that influence financial literacy among the youth particularly in Sibu, Sarawak, which highly contribute to their personal finance behaviour. Thus, there is a need to gain in-depth insight of UCTS students' perception towards their personal 
finance behaviour or management which may consecutively affect their main employment decision. These circumstances are examined by two research questions. Firstly, what are the prime factors to UCTS students on managing their personal finance? And secondly, what are the relations between each factor with the youth financial knowledge at UCTS?

The Theory of Planned Behaviour (TPB) was established by Ajzen (1991). It is an expansion of the range behaviours enclosed by the Theory of Reasoned Action (TRA). TPB clarifies and forecasts consumers purchase behaviour that is not totally under volitional control. This is done by including possession of necessary opportunities and resources in relation to control beliefs; the beliefs to perform a certain behaviour. Wherein this study, the greater the perceived behavioural control over their personal finance behaviour, the more opportunities and resources a consumer thinks they have or perceived power (Bulletin \& Amherst, 2016). Financial attitudes are beliefs strength, while principles evaluation financial socialization agents are functions of normative opinions and motivation to comply. Whereas, financial knowledge is suggested to be a task of financial literacy and apparent control.

Objective of the Study

The objective of this study is to examine specific factors associated with students' behaviour in managing their personal financial which could provide valuable information to an educational learning community.

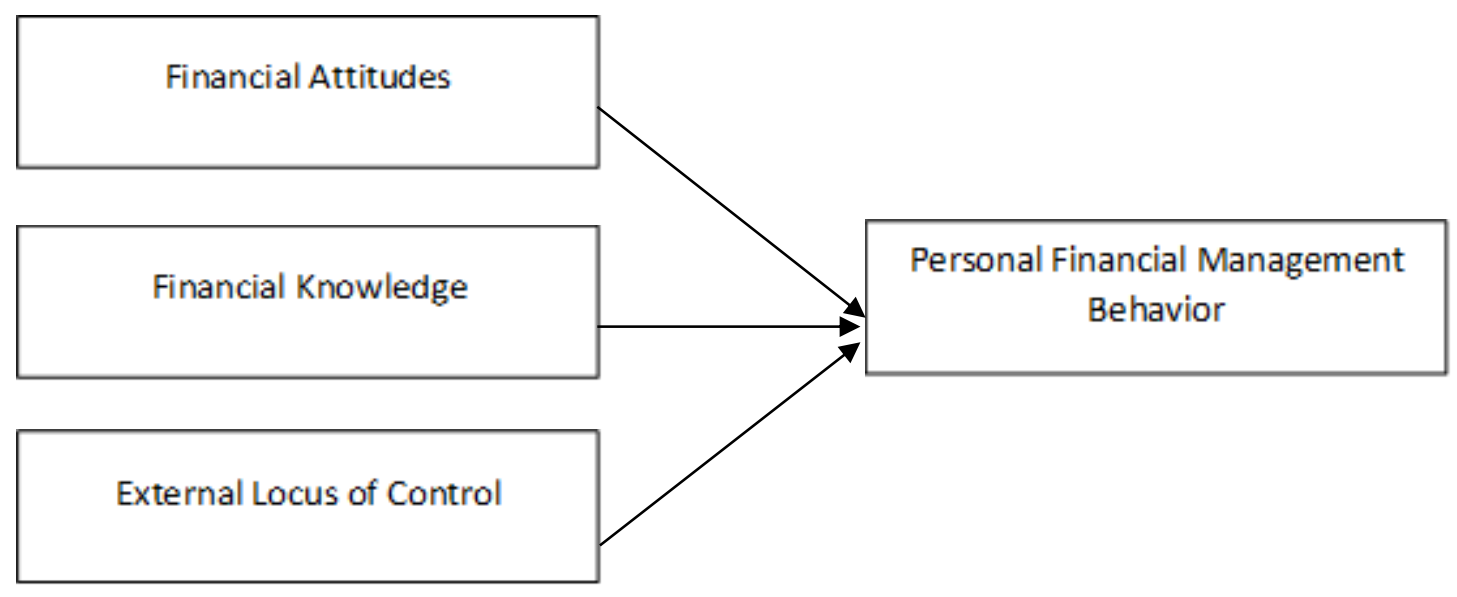

Figure 1: A Theoretical Framework of Planned Behaviour Source: Ajzen, 1991

\section{Methodology}

Qualitative variables from the interview were analysed to obtain the primary data. The sampling for this study was selected among UCTS Foundation and Degree students. Every methodologist is different by providing dissimilar range of sampling in diverse 
point of time. For example, at least 20 to 30 interviewees are advised for grounded theory studies by Creswell (2007). For this study, 20 respondents participated in the process of collecting the data.

Semi-structured interview was conducted with all respondents. A set of questions was prepared for the planned scope of the interview. An interview guide was developed as an orientation for the interviewers. The target of the interview was to obtain individual dialogue between interviewer and interviewee (Uwe Flick, 2011). Pole and Lampard (2002) stated that the guide and procedure are constructed accordingly in order to keep good direction during the interview. Furthermore, the structured interview was important so that all the facilitated analysis is covered within the interview conversation with proper categories. This study also comprised some open-ended questions and the followup questions to encourage the respondents to express their own views (Creswell, 2007). There were a few unforeseen topics which need to be considered before and during the interview. Therefore, a guide for semi-structured interview questions was prepared in order to prevent misdirection of the topics during the interview session.

\section{Literature Review}

According to Dew and Jing (2011), a certified financial management behaviour scale occurs and examiners normally practice substitutions of financial management behaviour, for instance, the real stages of customer debt relatively than measuring the behaviour itself(Bernstein, 2004). The most significant findings of scales characteristics are the valuation of several domains of financial management behaviour (Xiao, 2008). Psychometric endorsement, and endorsement using a nationwide descriptive model of adults. Financial management behaviour scales integrate the clue that individuals resolve consecutively embracing worthy financial management behaviours. For instance, a nationwide finding of the customers has shown an ordered outline of financial management behaviours (Hilbert et al, 2003). According to the survey done by Dew and Jing (2011), a slow interest in financial managing behaviour through money controlling established first, then credit reserves, and lastly investment administration.

An earlier study examined the outcome of financial attitude in future on socialization. The reason for the investigation was to discover the connection among financial socialization, perceived norms and materialism of the university students while monitoring for socio-economic features (Bulletin \& Amherst, 2016). The research was examined at a state university in Ankara involving perceived norms, social learning opportunities, and socialization agent that were significantly related to materialism confirmed by the regression results (Zeynep, 2010).

Apart from that, the Financial Management behavior scales (FMBS) measured financial management behaviour that might precede cash management to assess money administration, savings and investments, credit use and insurance, in which lead to ingesting management since almost entirely persons are buyers. Otherwise, consumers might show behaviour that would capitalize on their ingesting welfares (Dew \& Xiao, 2011). Actual scales usually will be called "Shopping and Purchases," where Dew \& Xiao (2011) hypothesized that people prefer strategies to manage their purchase compared to cash-flow management behaviour.

To summarise, Family Resource Management Theory, Theory of Planned Behavior (TPB) and Theory of Financial Management Behaviour scale could provide 
the theoretical framework to study personal finance management and finance management. The expansion of the range behaviours is covered by the Theory of Planned Behavior (TPB). While the third theory, to measured financial management behaviour that might lead to cash management in the FMBS as all persons are basically buyers.

\section{Findings}

Table 1 shows the demographic profile of 20 respondents. Personal finance management is relatively common to all students including students of University College of Technology Sarawak (UCTS). There were three items in the demographic profile section. As shown in Table 1, an equal distribution for both genders in order to get unbiased data from the respondents. Based on the data, most of the respondents were Chinese as they are the majority in the target population.

Table 1: Percentage Distribution

\begin{tabular}{llcc}
\hline Variables & Particulars & Frequency & Percentage \\
\hline Gender & Male & 10 & 50.00 \\
& Female & 10 & 50.00 \\
Race & Malay & 5 & 25.00 \\
& Chinese & 12 & 60.00 \\
& Iban & 2 & 10.00 \\
Age & Other & 1 & 5.00 \\
& 19 & 14 & 70.00 \\
& 20 & 4 & 20.00 \\
& 21 & 2 & 10.00 \\
\hline
\end{tabular}

\section{What is the factor that is prime to UCTS students on managing their personal finance?}

\section{Personal Financial Behavior (FB) - (Parental Influence)}

The respondents behavior were affected by their parents as the data of the interview sessions portrayed five out of twenty respondents were being influenced by their parents when it comes to their decisions in purchasing goods or services.

"I usually go to all shops, and then compare the products and services that I want to buy. Normally I will compare the price and the quality. But I compare the price of the products or service. I pay tuition fees using my parents' money. Usually, my parents will direct bank in my into the Edusar account (UCTS financing) for the tuition fees payment and normally for self-paying, it will not be on time, like 2 days late from the actual date. For the method of keeping track of my monthly expenses, I'll keep all my expenditure receipts and normally $i$ will stay within my budget or spending plan."

(Female respondent: Interviewee 1) 
"I will compare the prices when I purchase the thing because when even I purchase something, I always go with my parent, and normally the in practice is to survey the price, and as a student, I think that is a good thing when we have the skills to compare the prices. Price will be number one priority for me, then I will go for the quality, then only I will go for the brand when it comes to purchasing items or services."

(Female respondent: Interviewee 15)

"Normally I will compare the prices because it involves with my parents' money when I decide to purchase because I haven't earned my own money."

(Male respondent: Interviewee 18)

These findings showed that they are still under the obligations of their parents. However, for the older-age students (20 to 21 years old), they seemed to be more independent in terms of managing their personal finances. In terms of behavior, the results from the interview indicated that most of the respondents had positive personal finance behaviour. For cash management section on the spending behavior management, $80 \%$ of the respondents normally will compare the prices for goods or services before they purchase an item or service. Based on the respondents' answers during the interview session, this study examined that the influence of family members is a significant factor for UCTS students in managing their finance in terms of cash management. Therefore, most of the information that respondents shared were related to financial control by comparing the prices and keeping track of their expenditures by keeping the purchasing receipts.

"I do have my own investment which is Amanah Saham Bumiputra (ASB). I have just been exposed by my parent and they handle it for me. I do save sometimes and I save RM20-RM50 on average per month. This is catered for emergency or when I want to buy something."

(Female respondent: Interviewee 2)

"I have an investment because my mother asks me to save at Amanah Saham Bumiputra (ASB). I have two types of savings. I collect the huge 50 cents as my hobby and the RM 10 each day is for my future use savings." (Male respondent: Interviewee 4)

"I do have investments', Saham, MBI, Solar Bond. My parents help me to do the investments. I have my savings but not every month I save, only for food and my personal use."

(Male Respondent: Interviewee 5)

"I have my investment but it is managed by my parents and I don't really know in details for now. I save RM 5000 every six months because my father will give me RM5000 every six months for my pocket money and I save because I want to fulfil my goals and my aims." 


\section{(Male respondent: Interviewee 6)}

Another finding indicated that most of the respondents were able to differentiate between savings and investment. Data shown that there is a positive relation between each of the factors with the youth financial knowledge for students in UCTS as most of them had been exposed to savings and investments products by their family. $85 \%$ of respondents reported that they are have at least one investment. Respondents specified that they choose to invest in Amanah Saham Bumiputra (ASB) for the investment. From this finding, it clearly shows that personal financial behaviour management is influenced by the demographic background, in which ASB is the product for Bumiputra investment. With this outcome, it strongly signifies that there is a positive relationship between the factors and their personal finance.

\section{What are the relations between each factor with the youth financial knowledge at UCTS?}

\section{Financial Knowledge (FK)}

Financial knowledge has been known as one of the most significant variables when it comes to managing personal finance, especially among the university students.

"I'm not sure about the rates or charges. I can read the amount of my bank balance after I withdraw the money and from there, I will know how I can spend money later. My overall opinion in managing personal finance is on how one actually spends."

(Female respondent: Interviewee 2)

"I don't know the financial rates. I don't remember because I don't want to. I think managing personal finance is not to waste the money too much." (Female respondent: Interviewee 3)

"No, I don't know about the borrowing rate. Normally we will remember after the last withdraw to monitor how much left to spend next. Managing personal finance is a good thing to practice so that our finance will be more organized."

(Female respondent: Interviewee 9)

"I don't know about the borrowing rates or charges. Sometimes only I remember, sometimes no, because if I'm out of money, I can still ask for cash from my parents. Overall, managing personal finance is about how we spend and save."

(Male respondent: Interviewee 19)

"I have been exposed to some borrowing rates charged, for example, for CIMB is 6\%. I do remember to keep track of how much I spend and after that, I can control my spending if I already know. Managing personal finance can be in a different way, for example, I do invest in gold and the more we save, the better it will be for a student."

(Male respondent: Interviewee 18) 


\begin{abstract}
"I know PTPTN borrowing rates charge only 1\% because I normally use the Internet to buy a thing so I usually remember the balance of my bank account. Managing personal finance is not so easy for everyone especially for students."

(Male respondent: Interviewee 4)
\end{abstract}

The findings indicated that financial knowledge influences UCTS students in term of managing personal finance behavior. Besides, a number of respondents consisting of the foundation students in UCTS also equip themselves with the financial knowledge. They are educated and informed on the issues of managing money, the borrowing rates or charges by any of financial providers, bank statement reading and the understanding about managing personal finance and financial products that they pursue.

However, two male respondents claimed that they have some basic ideas regarding saving and investment products, which are managed by their parents. It indicated that male students at UCTS seem to have more awareness and concern regarding their finance management. Thus, interests in financial knowledge differed according to genders.

\title{
Financial Attitude (FA)
}

Financial attitude is also an important variable that may influence the students in term of the factor that would lead them on managing their personal finance. It examined the financial habits that would determine this variable to become one of the factors. Furthermore, this section inquired several open-ended and subjective questions. Overall, there is a positive relationship between students' financial attitude and their financial management behaviour. As they gradually practice financial management, their habits of financial practices have been improved and they are more concerned with financial issues.

"I don't save fixed amount of cash every month. It is important to save in a fixed amount, but currently as a student, I do not need to have the habit. I think I should write down my financial goals so that I can stay focused on the goals and the plan to earn and spend no more than I save. I agree that each individual should be responsible for their own financial wellbeing when it comes to an emergency situation to cover myself, as I depend much on myself. But planning for spending money is essential to successful life management because we can learn to keep own money for future use."

(Male respondent: Interviewee 12)

"I don't save in a fixed amount of cash for every month and I think it is important to save even it is not in the fixed amount. I do think writing down the financial goals can help us to plan our finance well for the future. This statement depends on the situation and I partially will agree as a student, I still am dependent in terms of financial wellbeing 
because I don't earn my own money. But if we plan for spending money in future, we can learnt a lot about finance and once we experience we can think others as well based on my experience."

(Female respondent: Interviewee 14)

"I usually don't save a fixed amount because the amount of money that I get for my pocket money is also not fixed. I do not need to have financial goals currently. The statement I would agree with depending on the situation. Sometimes, humans can be too dependable in terms of finance and a lot of students nowadays at University have their part-time jobs, they do not really depend on others too much in terms of money, just for a small necessity. However, money planning will lead to a successfully managed life because once we get involved in borrowing, we will have the commitment and we must plan to pay or else our life will be hard to manage."

(Male respondent: Interviewee 10)

The outcomes indicated that most of students did not have the fixed savings of cash, as they are still too dependent on their family especially parents. Apart from that, they did not receive a fixed amount of pocket money that could impede them to save. However, they were still agree on money planning which could help them to manage their personal finance in future even they do not have a fixed amount of saving. This showed that the UCTS students do have the knowledge about managing their personal finance. However, when it comes to the implementation, they do not think it is important to have their own savings since they are still relying on their parents. UCTS students' knowledge on personal finance did not really affect their attitude either to start save or plan for their finance, even they knew the significance of managing their personal finance.

\section{External Locus Control (LC)}

The final aspect that was analysed in this study was External Locus Control (LC), which refers to to the students' financial problem that occurs in a specific amount of time. The findings revealed that the respondents were depending on their parents to manage their money.

"Most of the time I will face difficulties when I don't have enough money for that particular month because I live far from my parents, so I will not buy something that I just don't need. Usually I never faced a situation like this because currently I still a student and my parents will help me if I face some personal finance problems."

(Female respondent: Interviewee 2)

"Most of the time I tend to follow what my parent set for me". (Female respondent: Interviewee 1)

Approximately $40 \%$ of the respondents could not be determined and rationale when they face financial problems. This can be interpreted as students could not control and manage their own financial issues. There was a trust issue among parents in giving 
full authority to their children to manage their own finance. The age could be one of the factors too, as most parents have the perspective that their children, who are still students, are immature in handling financial matters.

The discussion for the last findings was mainly related to the decision making for the payment method in purchasing luxury items. The interview disclosed that most of the students choose the item and the payment method based on their preferences. Nowadays, the payment method is much more advanced in terms of the technology application which is more convenient for the youth. Most of them would pay via Internet banking which is easier to access through their mobile phone.

" For most of the purchasing decision for a luxury item I will decide by myself, for example, when I purchase my laptop and hand phone, I will look for the functions, brand and then only the price, and the payment method that I comfortable with is by using Internet banking as it is easy to access."

(Female respondent: Interviewee 15)

The overall findings of this study discovered that all the analyzed data tend to corroborate to the factors of managing the personal financial among the students in University College of Technology Sarawak (UCTS), particularly among the Foundation students. It affirmed that the management on the personal financial behaviour did influence the three variables that had been used in the conceptual model, which were financial knowledge (FK), financial attitude (FA) and the external locus control (LC).

\section{Limitations and Recommendations}

One of the limitations in conducting this study was the qualitative data collected through the interview tend to reveal the respondents' personal savings, which could be confidential. As a result, some of the respondents were reluctant to share their personal financial information, which could lead to deficient amount of information for this study. Another limitation for the study was that not all the respondents were applying their obtained knowledge on financial management because they perceived it as a violation of their privacy. Due to respondents' immaturity, a lot of financial decisions were influenced or made by their parents, which could limit the respondents' experience in giving sufficient and comprehensive feedback during interview sessions.

Thus, it is highly recommended that financial knowledge, such as talk, to be conducted to new students as well as their parents, during the freshman orientation week. The main purpose of financial knowledge is to raise awareness of the importance of personal finance to students. In addition, as for the future, this set of interview questions can be applied through different cohorts of students across different schools to understand their personal financial behaviour. 


\section{Conclusion}

The results indicated that personal financial management among the UCTS students has been influenced by the factors that have been discussed in the findings. It's showed that the positive relationship between the students managing behaviour with financial knowledge (FK), where by most of them gained financial knowledge from their family. The findings also stated the positive association between the student's financial management behaviour (FB) and financial attitude (FA), as students seemed to understand the importance of having a financial saving and a future plan for financial savings after working, even though currently, most of them do not have early savings. The relation between student's financial behaviour and external lotus control (LC) has shown a strong relationship as parents and family play a major role in determining their decisions when financial obstacles occur. Generally, this study examines the primary factors of financial management among UCTS students. The data confirmed that there are strong relations between each factor with the youth financial knowledge at UCTS. Hence with this issue in hand, it is strongly recommended that the existing practices should be improved and the new management practices to be introduced and implemented at the university level to increase students' awareness towards effective financial management.

\section{References}

Agarwalla, S. K., Barua, S. K., Jacob, J., \& Varma, J. R. (2015). Financial Literacy among Working Young in Urban India. World Development, 67(2013), 101-109. http://doi.org/10.1016/j.worlddev.2014.10.004

Birari, A., \& Patil, U. (2014). Spending \& Saving Habits of Youth in the City of Aurangabad. The Standard International Journals, 2(3), 158-165.

Braunstein, S., Welch, C., \& Affairs, C. (n.d.). 1102Lead.

Bulletin, S. P., \& Amherst, M. (2016). A Comparison of the Theory of Planned Behavior and the Theory of Reasoned Action, (May). http://doi.org/10.1177/0146167292181001

Chowa, G. A. N., Despard, M., \& Osei-Akoto, I. (2012). Financial Knowledge and Attitudes of Youth in Ghana. Washington University in St. Louis Center for Social Development, 2, 1-7.

Danes, S. M., \& Hira, T. K. (1987). Money Management Knowledge of College Students. Journal of Student Financial Aid, 17(1), 3-16.

Dew, J., \& Xiao, J. J. (2011). The Financial Management Behavior Scale : Development and Validation, (435), 43-59.

Falahati, L., \& Paim, L. H. (2011). Toward a framework of determinants of financial management and financial problems among university students, 5(22), 96009606. http://doi.org/11.5897/AJBM11.1293

Fallis, A. (2013). No Title No Title. Journal of Chemical Information and Modeling, 53(9), 1689-1699. http://doi.org/10.1017/CBO9781107415324.004

Goetz, J., Cude, B. J., Nielsen, R. B., Chatterjee, S., \& Mimura, Y. (2011). CollegeBased Personal Finance Education: Student Interest in Three Delivery Methods. Journal of Financial Counseling and Planning Volume 22 Issue 1, (706), 27-42. Retrieved from http://content.ebscohost.com/pdf27_28/pdf/2011/7E6/01Jul11/66913480.pdf?T=P $\& \mathrm{P}=\mathrm{AN} \& \mathrm{~K}=66913480 \& \mathrm{~S}=\mathrm{R} \& \mathrm{D}=\mathrm{a} 9 \mathrm{~h} \&$ EbscoContent $=\mathrm{dGJ}$ MNLe80SeqLE4 $\mathrm{v}+$ 
vlOLCmr0qep7JSsKa4Sa+WxWXS\&ContentCustomer=dGJyMPGusk+yrLBRue Pfgeyx 64 fg $3+\mathrm{p} 9$

Grable, J. E. E. Al. (2005). Tools, Techniques, Strategies, and Research to Aid Consumers and Professional Financial Advisors. Journal of Personal Finance, 4(4).

Jurevičienè, D., \& Ivanova, O. (2013). Behavioral FINANCE : THEORY AND SURVEY, 5(1), 53-58. http://doi.org/10.3846/mla.2013.08

Kim, J., \& Chatterjee, S. (2013). Childhood Financial Socialization and Young Adults ' Financial Management. Journal of Financial Counseling and Planning, 24(1), $61-79$.

Lusardi, A., \& Mitchell, O. S. (2014). The Economic Importance of Financial Literacy: Theory and Evidence. Journal of Economic Literature, 52(1), 5-44. http://doi.org/10.1257/jel.52.1.5

Mitchell, O., Lusardi, A., \& Curto, V. (2009). Financial Literacy Among the Young: Evidence and Implications for Consumer Policy. Pension Research Council WP, 1-35. http://doi.org/10.2139/ssrn.1476982

Ngoc Mien, N. T., \& Thao, T. P. (2015). Factors Affecting Personal Financial Management Behaviors : Evidence from Vietnam. Preconference on Global Business, Economics, Finance \& Social Sciences, 10-12.

S 4Dollahite91.pdf. (n.d.).

Schuchardt, J., Bagwell, D. C., Bailey, W. C., Devaney, S. a, Grable, J. E., Leech, I. E., ... Xiao, J. J. (2007). Personal Finance : An Interdisciplinary Profession. Financial Counseling and Planning, 18(1), 61-69. Retrieved from http://scholar.google.com/scholar?hl=en\&btnG=Search\&q=intitle:Personal+Finan ce+: + An+Interdisciplinary+Profession\#0

Shim, S., Barber, B. L., Card, N. A., Xiao, J. J., \& Serido, J. (2010). Financial Socialization of First-year College Students: The Roles of Parents, Work, and Education. Journal of Youth and Adolescence, 39(12), 1457-1470. http://doi.org/10.1007/s10964-009-9432-x 